\title{
Reduced $\beta_{1}$ Receptor Messenger RNA Abundance in the Failing Human Heart
}

\author{
Michael R. Bristow, * Wayne A. Minobe, * Mary V. Raynolds, * J. David Port, * \\ Randy Rasmussen, ${ }^{*}$ Phillip E. Ray, ${ }^{3}$ and Arthur M. Feldman ${ }^{5}$ \\ *Temple Hoyne Buell Laboratories, Division of Cardiology, University of Colorado Health Sciences Center, Denver, Colorado 80262; \\ ${ }^{\ddagger}$ Department of Biology, University of Utah, Salt Lake City, Utah 84112; and ${ }^{\S}$ The Peter Belfer Laboratory for the Molecular Biology \\ of Heart Failure, The Johns Hopkins University School of Medicine, Baltimore, Maryland 21205
}

\begin{abstract}
Heart failure in humans is characterized by alterations in myocardial adrenergic signal transduction, the most prominent of which is down-regulation of $\beta_{1}$-adrenergic receptors. We tested the hypothesis that down-regulation of $\beta_{1}$-adrenergic receptors in the failing human heart is related to decreased steady-state levels of $\beta_{1}$ receptor mRNA. Due to the extremely low abundance of $\beta_{1}$ receptor mRNA, measurements were possible only by quantitative polymerase chain reaction (QPCR) or by RNase protection methods. Because the $\beta_{1}$ receptor gene is intronless and $\beta_{1}$ receptor mRNA abundance is low, QPCR yielded genomic amplification in total RNA, and mRNA measurements had to be performed in poly $(A)^{+}$-enriched RNA. By QPCR the concentration of $\beta_{1}$ receptor $m R N A$ varied from 0.34 to $7.8 \times 10^{7}$ molecules $/ \mu$ goly $(A)^{+}$-enriched RNA, and the assay was sensitive to 16.7 zeptomol. Using 100 -mg aliquots of left ventricular myocardium obtained from organ donors (nonfailing ventricles, $n=12$ ) or heart transplant recipients (failing ventricles, $n=13$ ), the respective $\beta_{1}$ mRNA levels measured by QPCR were $4.2 \pm 0.7 \times 10^{7} / \mu \mathrm{g}$ vs. $2.10 \pm 0.3$ $\times 10^{7} / \mu \mathrm{g}(P=0.006)$. In these same nonfailing and failing left ventricles the respective $\beta_{1}$-adrenergic receptor densities were 67.9 $\pm 6.9 \mathrm{fmol} / \mathrm{mg}$ vs. $29.6 \pm 3.5 \mathrm{fmol} / \mathrm{mg}(P=0.0001)$. Decreased mRNA abundance in the failing ventricles was confirmed by RNase protection assays in total RNA, which also demonstrated a $50 \%$ reduction in $\beta_{1}$ message abundance. We conclude that down-regulation of $\beta_{1}$ receptor mRNA contributes to down-regulation of $\beta_{1}$ adrenergic receptors in the failing human heart. (J. Clin. Invest. 1993. 92:2737-2745.) Key words: $\beta$-adrenergic $\bullet$ heart failure $\bullet$ messenger RNA $\bullet$ polymerase chain reaction $\cdot$ receptor
\end{abstract}

\section{Introduction}

The failing human heart is characterized by desensitization to adrenergic stimulation (1-5), which results in attenuation of the ability of the heart to increase contractility during exercise or physiologic stress. The majority of this subsensitivity to adrenergic drive is the result of a selective down-regulation of the myocardial $\beta_{1}$-adrenergic receptor (2-5). In the failing hu-

Address reprint requests to Dr. Michael R. Bristow, Temple Hoyne Buell Laboratories, Division of Cardiology, University of Colorado Health Sciences Center, Denver, CO 80262.

Received for publication 12 November 1992 and in revised form 21 July 1993

J. Clin. Invest.

(c) The American Society for Clinical Investigation, Inc.

$0021-9738 / 93 / 12 / 2737 / 09 \$ 2.00$

Volume 92, December 1993, 2737-2745 man heart ventricular myocardial $\beta_{1}$-adrenergic receptors appear to be down-regulated in all subcellular fractions (4). Since there is no significant $\beta$ receptor reserve in the human heart (6, 7 ), $\beta_{1}$ receptor density is a major control point in the regulation of contractility (5). Less clear are the molecular alterations responsible for myocardial $\beta_{1}$-adrenergic receptor down-regulation in the failing human heart.

In model systems the steady-state abundance of $\beta_{2}$-adrenergic receptor mRNA and receptor protein levels correlate closely $(8,9)$. Further, studies in cultured heart cells $(10,11)$ suggest that the same relationship between mRNA abundance and receptor expression may also exist for the $\beta_{1}$-adrenergic receptor subtype. Accordingly, we tested the hypothesis that, in the human heart, the steady-state abundance of $\beta_{1}$-adrenergic receptor mRNA would correlate with $\beta_{1}$ receptor expression at the protein level. Because of the extremely low abundance of $\beta_{1}$ receptor mRNA, we measured $\beta_{1}$ receptor mRNA levels by quantitative polymerase chain reaction $(\mathrm{QPCR})^{1}(12-14)$ or by RNase protection (15) assays. Using QPCR with poly $(\mathrm{A})^{+}$enriched RNA as the starting material or RNase protection in total RNA, the data support the premise that down-regulation of $\beta_{1}$-adrenergic receptors in failing human ventricular myocardium is related to decreased $\beta_{1}$-adrenergic receptor mRNA abundance.

\section{Methods}

\section{Tissue procurement}

Human ventricular myocardium was obtained from subjects undergoing heart or heart/lung transplant, and from organ donors whose hearts were unsuitable for donation owing to blood type or size incompatibility. 15 nonfailing left ventricles were taken from 14 organ donors and one subject undergoing heart/lung transplantation, with all 15 hearts having normal left ventricular function determined by echocardiography. Failing left ventricular myocardium was taken from 13 subjects with end-stage left ventricular failure due to idiopathic dilated cardiomyopathy who underwent heart transplantation. These subjects were not receiving intravenous $\beta$-adrenergic receptor agonists, phosphodiesterase inhibitors, or antagonists before transplantation. Mean age of the nonfailing controls was $28.8 \pm 5.1$ (SEM) $y r$, compared with $41.7 \pm 4.7 \mathrm{yr}$ for the subjects with heart failure $(P=\mathrm{NS})$. Eight of the nonfailing controls were female, and seven were male. Of the failing subjects, 11 were male and two were female.

All subjects with end-stage heart failure had New York Heart Association class IV symptoms before transplantation. Their hemodynamic data included a left ventricular ejection fraction of $0.16 \pm 0.01$, cardiac index of $2.01 \pm 0.23 \mathrm{liter} / \mathrm{min} / \mathrm{m}^{2}$, mean pulmonary capillary wedge pressure of $20.5 \pm 2.3 \mathrm{mmHg}$, mean pulmonary artery pressure of $30.5 \pm 2.6 \mathrm{mmHg}$, and mean right atrial pressure of $6.6 \pm 2.3 \mathrm{mmHg}$.

Tissue aliquots were removed from the still-beating heart immediately upon explantation, and either immersed in liquid nitrogen (see 
below) or placed in ice-cold, oxygenated Tyrode's solution as described previously (2).

\section{$R N A$ extraction}

1-g aliquots of human left ventricular mid free wall were removed on explantation, immediately immersed in liquid nitrogen, and stored at $-70^{\circ} \mathrm{C}$ until used. Poly $(\mathrm{A})^{+}$-enriched $\mathrm{mRNA}$ was extracted from 50 100-mg aliquots of human left ventricular myocardium using oligo(dT) cellulose (Micro-FastTrack ${ }^{\mathrm{TM}}$ mRNA Isolation Kit Ver. 1.2, Invitrogen Corp., San Diego, CA). Total RNA was extracted from separate $50-100-\mathrm{mg}$ aliquots by the acid guanidinium thiocyanate phenol-chloroform method (16) using RNA Stat-60 (TelTest, Inc., Friendswood, TX), as previously described (13).

\section{Quantitative PCR}

$\beta_{1}$ receptor $m R N A$ measurement. The basic technique for measuring mRNA abundance by QPCR in small aliquots of human heart has been previously described (16). The ethanol precipitated pellet of extracted poly $(\mathrm{A})^{+}$-enriched RNA $(0.8-3.2 \mu \mathrm{g})$ was dissolved in $16 \mu \mathrm{l}$ of diethyl pyrocarbonate-treated $\mathrm{H}_{2} \mathrm{O}$, and a $4-\mu \mathrm{l}$ aliquot was directly measured by a capillary spectrophotometer (model DU-64, Beckman Instruments, Inc., Fullerton, CA). For RNA extracted from both nonfailing and failing hearts $200 \mathrm{ng}(1-4 \mu \mathrm{l})$ of the remaining $12 \mu \mathrm{l}$ of RNA was then added to the reverse transcriptase reaction, along with $0.5 \mathrm{pg}$ of a synthetic (84mer) cRNA "internal" standard (17). The reverse transcriptase reaction was carried out according to manufacturer's instructions (Promega Corp., Madison, WI), using a 20- $\mu$ l reaction volume, $\mathrm{RNase} \mathrm{H}$-free Moloney murine leukemia virus reverse transcriptase, and random primers. The synthetic RNA (or cRNA) was generated by an in vitro transcription reaction from synthetic DNA templates having a T7 RNA polymerase promoter sequence. The cRNA was DNAse (RNase free) treated, phenol/chloroform extracted, and ethanol precipitated before resuspension and quantification by spectrophotometry. The amount of cRNA added to the reverse transcription reaction was determined experimentally to ultimately yield collinear amplification of the $\beta_{1}$ receptor and internal standard cDNAs.

Extensive characterization of amplification of reverse transcribed $\beta_{1}$ receptor mRNA resulted in selection of the following optimal conditions: $2 \%$ DMSO and $2 \mathrm{mM} \mathrm{MgCl}_{2}$ in the Taq polymerase buffer, the use of $\mathrm{RNase} \mathrm{H}$ to degrade the RNA strand in the RNA:cDNA duplex after reverse transcription, $50 \mathrm{pmol}$ of each primer, and $4 \mathrm{U}$ of Taq polymerase (Promega Corp.) per $100-\mu$ l reaction. Additionally, the reaction mixture was denatured at $94^{\circ} \mathrm{C}$ for $5 \mathrm{~min}$, then cooled to the annealing temperature of $55^{\circ} \mathrm{C}$ for $2 \mathrm{~min}$, and brought to the $72^{\circ} \mathrm{C}$ extension temperature before Taq polymerase was added (18). Typically a 4- $\mu$ l aliquot of the reverse transcriptase / RNAse H-treated reaction was used in the PCR reaction, with a final volume of $100 \mu$ l.

The primers utilized in the $\beta_{1}$ receptor PCR reaction spanned a 202-bp segment of the human $\beta_{1}$ cDNA sequence $(+150$ to +351 [17]) and incorporated restriction enzyme recognition sites at the 5 ' ends for use in the cloning of this segment for other purposes. The sequences were: $5^{\prime} \cdot$ CCGAATTCCGAGCCGCTGTCTCAGCAGTGGACA - 3' for the $5^{\prime}$ primer and $5^{\prime} \cdot$ CCAAGCTTGGTGGCCCCGAACGGCACCACCAGCA $\cdot 3^{\prime}$ for the $3^{\prime}$ primer. For subsequent quantification of $P C R$ product yield after gel electrophoretic separation, an aliquot of the $3^{\prime}$ primer was end-labeled with $\left[\gamma^{32} \mathrm{P}\right]$ ATP using T4 polynucleotide kinase (Promega Corp.). All DNA oligonucleotides were purchased from Operon Technologies, Alameda, CA. As described previously (13), 10- $\mu$ laliquots were removed from sequential amplification cycles (15 through 33) and fractionated with molecular weight standards by agarose gel electrophoresis. Specific product bands were located by ethidium bromide staining and ultraviolet irradiation, excised, and quantified by Cerenkov counting.

With this technique, separate amplification curves for the unknown cDNA and the internal standard cDNA were constructed. Since a known amount of synthetic RNA internal standard is carried through the cDNA synthesis and amplification, the original $\beta_{1}$ receptor mRNA level can be determined by extrapolation from the internal standard cDNA standard curve. It is essential that this extrapolation be performed during the exponential phase of amplification and that the curves for the unknown and internal standard are collinear, which occurred in all cases between cycles 20 and 30. An RNA sample not subjected to reverse transcription is run as a control for contamination by genomic DNA.

$\beta_{2}$ mRNA abundance was measured in total RNA with linear amplification occurring in all cases between cycle numbers 20 and 30 . The assay conditions for measuring $\beta_{2}$ receptor mRNA abundance by QPCR have been previously described $(13,19) ; 1 \mu \mathrm{g}$ of total RNA from both failing and nonfailing groups plus $30 \mathrm{pg}$ of cRNA was used in the reverse transcriptase reaction. Typically a $1 \mu \mathrm{l}$ aliquot of the reverse transcriptase/RNase $\mathrm{H}$ treated reaction was used in the PCR reaction.

Measurement of $\beta_{1}$ receptor $m R N A$ by $R$ Nase protection. The human $\beta_{1}$-adrenergic receptor CDNA (17) was subcloned into pBluescript II KS (Stratagene, Inc., La Jolla, CA) and digested with either Smal or EagI. Antisense RNA transcribed from the T3 promoter of the SmaI digested vector comprised $\sim 450$ bp of the terminal end of the $3^{\prime}$ untranslated region (Smal probe, probe I). Antisense RNA transcribed from the T3 promoter of the EagI digested vector contained $\sim 400 \mathrm{bp}$ of the $3^{\prime}$ end of the coding region and the entire $3^{\prime}$ untranslated region ( $700 \mathrm{bp})$ (EagI probe, probe II).

Antisense riboprobes were transcribed from the appropriately digested $\beta_{1}$ receptor cDNA using the Maxiscribe kit (Ambion, Inc., Austin, TX): The riboprobes were labeled by incorporation of $[\alpha-$ ${ }^{32} \mathrm{P}$ ]UTP $800 \mathrm{Ci} / \mathrm{mM}$ (New England Nuclear, Boston, MA) into the RNA during transcription with T3 DNA-dependent RNA polymerase. Approximately $1-2 \times 10^{5} \mathrm{cpm}$ of ${ }^{32} \mathrm{P}$-labeled antisense $\beta_{1}$ RNA was used in each nuclease protection assay.

Labeled riboprobes were hybridized in solution with 2 or $5 \mu \mathrm{g}$ of total RNA extracted from failing or nonfailing explanted hearts for 18 $\mathrm{h}$ at $44^{\circ} \mathrm{C}$. Unhybridized single-stranded RNA was digested with RNaseA and RNaseT1. RNA-RNA hybrids were resolved by electrophoresis in an $8 \%$ acrylamide denaturing gel and visualized by autoradiography at $-80^{\circ} \mathrm{C}$. The RPAII kit (Ambion, Inc.) was used for solution hybridization and RNase digestion.

Protected RNA species were quantified by densitometry. In all experiments in vitro transcribed $\beta_{1}$ receptor sense strand RNA generated by the same method from the same vector as the antisense riboprobes served as a positive control. In addition, in order to verify the specificity of the $\beta_{1}$ probes for $\beta_{1}$ mRNA, the synthetic full-length $\beta_{2}$ mRNA (20) was transcribed and $100 \mathrm{pg}$ hybridized with each of the two $\beta_{1}$ antisense riboprobes.

Hybridization intensity for protected RNA species of the appropriate size was measured by densitometry of autoradiograms developed for 2-7 d. Two or three nonfailing control samples were run on each gel and the OD reading averages of these samples gave the $100 \%$ or control value. Each sample from failing or nonfailing hearts was then referenced to this $100 \%$ value, with results reported as percentage of control.

$\beta$-Adrenergic receptor quantification. $\beta_{1}$ and $\beta_{2}$ adrenergic receptors were quantified in a crude membrane fraction prepared from 5-g aliquots of left ventricular free wall, using previously described methods (2). Briefly, the total population of $\beta_{1}$ plus $\beta_{2}$ receptors was measured by the nonselective radioligand $\left[{ }^{125} \mathrm{I}\right]$ iodocyanopindolol. Maximum binding $\left(B_{\max }\right)$ and the $\left[{ }^{125} \mathrm{I}\right]$ iodocyanopindolol dissociation constant $\left(K_{\mathrm{d}}\right)$ were determined by nonlinear least-squares computer modeling of the specific binding curve (2). Fractions of $\beta_{1}$ vs. $\beta_{2}$ receptors in the membrane preparations were determined by computer modeling of competition curves using the highly selective $\beta_{1}$ antagonist CGP$20712 \mathrm{~A}$ (4). Multiplication of the total $B_{\max }$ by the fraction of $\beta_{1}$ receptors obtained from CGP-20712A/[ $\left.{ }^{125} \mathrm{I}\right]$ iodocyanopindolol competition curves then yielded $\beta_{1}$ receptor density.

Protein concentrations were determined by the Peterson modification of the method of Lowry (21). RNA concentration and purity was determined by measuring absorbance at 260 and $280 \mathrm{nM}$ using a highly sensitive capillary spectrophotometer (Beckmann Instrument model DU-64). 


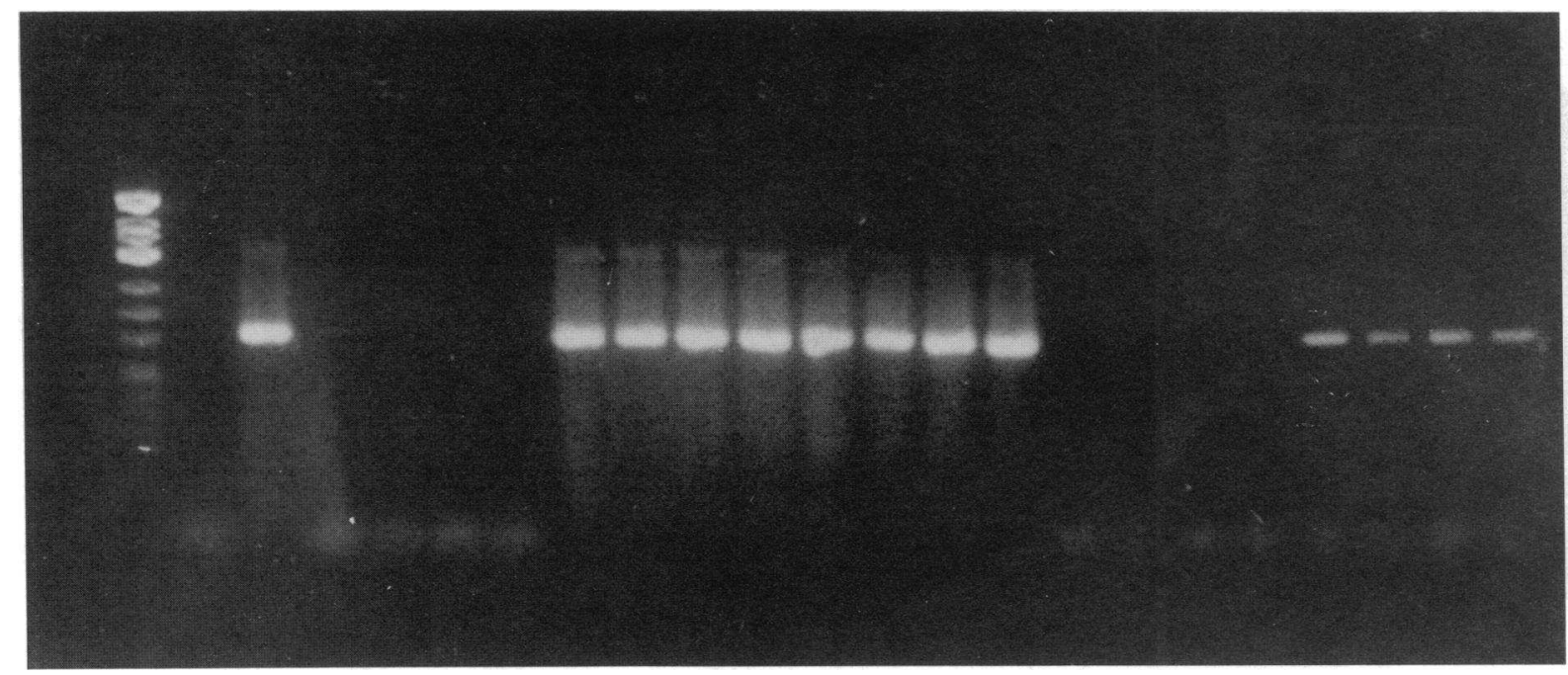

A $B$ C C D

Figure 1. Assessment of genomic DNA contamination levels between poly(A) ${ }^{+}$-enriched RNA $(H, I, J, K, P, Q, R, S)$ and total RNA $(L, M, N$, $O, T, U, V, W)$ fractions subjected to QPCR. $200 \mathrm{ng}$ of poly (A) ${ }^{+}$-enriched RNA and $1 \mu \mathrm{g}$ of total RNA extracted from two failing and two nonfailing hearts were added to duplicate reverse transcription reactions differing only in whether they contained reverse transcriptase or not. Subsequently, $10 \%$ of each of the total RNA reactions and $20 \%$ of the poly (A) ${ }^{+}$reactions were amplified by PCR. All the reverse transcription reactions with transcriptase ( $H, I, J, K, L, M, N, O$ ) show strong amplification of specific 202-bp product (compared with the positive synthetic $\beta_{1}$ receptor mRNA control, $(C)$ but of the reactions without transcriptase $(P, Q, R, S, T, U, V, W)$ only the poly (A) $)^{+}$-enriched RNA reactions $(P, Q, R, S)$ do not amplify the 202-bp product. $(A)$ DNA molecular weight markers. $(B)$ PCR reagent blank. $(C)$ Synthetic, full-length $\beta_{1}$ receptor mRNA/positive amplification control. $(D, E, F, G)$ Synthetic $\beta_{1}$ receptor mRNA/no reverse transcriptase controls.

\section{Statistical analysis}

Comparison of numerical data between two groups was by an unpaired t-test. Correlation analysis was by simple regression. All statistical computation was performed on the StatView $512+$ TM program (Brainpower, Inc., Calabasas, CA). Statistical significance was taken as $P$ $<0.05$ in a two-tailed distribution.

\section{Results}

\section{$Q P C R$}

$\beta_{1}$ receptor $m R N A$ abundance. Shown in Fig. 1 is a $4 \%$ agarose gel stained with ethidium bromide in which were run PCR products generated from four samples each of total and poly $(\mathrm{A})^{+}$-enriched RNA, extracted from two nonfailing and two failing human ventricles. In the absence of reverse transcriptase [RT $(-)$ condition], genomic material of the expected size for the $\beta_{1}$ receptor PCR product is clearly present in the total RNA samples after 38 cycles. In contrast, poly $(\mathrm{A})^{+}$enriched RNA shows no amplification under $\mathrm{RT}(-)$ conditions. Based on these results we used poly $(\mathrm{A})^{+}$-enriched RNA as the starting material for QPCR quantification of $\beta_{1}$ mRNA abundance.

Fig. 2 shows an ethidium stained $4 \%$ agarose gel in which were separated the contents of six PCR reactions using $\operatorname{poly}(\mathrm{A})^{+}$-enriched RNA as the starting material. The amplified cDNAs were made by reverse transcribing 36-44 $\mathrm{ng}$ of poly $(\mathrm{A})^{+}$-enriched RNA extracted from six samples of human left ventricle (designated $A, B, C, D, E$, and $F$ ) along with 200-500 fg of the internal standard cRNA. Each PCR reaction is represented by a set of nine sequential $10-\mu$ l aliquots which were removed from the reaction tube at (left to right) cycles 14 , $17,19,21,24,25,27,29$, and 32. The PCR amplification product for $\beta_{1}$ receptor mRNA appears as a 202-bp band, while the internal standard appears as an $84-b p$ band. The gel also includes "genomic controls": that is, poly $(\mathrm{A})^{+}$-enriched RNA from the six samples (labeled, respectively, $G-L$ ) not subjected to reverse transcription. There was progressive amplification of the target mRNA and the internal standard cRNA in all six samples $(A-F)$. However, there was no amplification of genomic DNA in any sample $(G-L)$. Identity of the 202-bp band was confirmed by direct PCR sequencing (22).

Fig. 3 shows amplification curves from four individual samples (two failing and two nonfailing) using 1.9-11.4 fg of internal standard cRNA per ng of poly $(\mathrm{A})^{+}$RNA. It can be seen that there is collinear amplification between 20 and 30 cycles; curves were accepted for analysis only if amplification was linear for at least six cycles.

In order to compare the efficiency of reverse transcription of the internal standard cRNA to that of the $\beta_{1}$ receptor mRNA, we measured by QPCR a dilution series of cDNAs reverse transcribed from known, equal amounts (16.7 zeptomol to 16.7 amol of each; or $10^{4}$ to $10^{7}$ molecules) of the cRNA and full-length $\beta_{1}$ receptor mRNA. The latter was generated by in vitro transcription from a pBluescript IIKS phagemid expression vector. An amplification curve was constructed for each concentration of the series, and quantities of mRNA vs. cRNA were calculated from equivalent points in the exponential phase of amplification. As shown in Fig. 4, the incorporation of labeled primers into the PCR products made from the internal standard cRNA was essentially identical to those for the full-length $\beta_{1}$ receptor mRNA. In order to determine if the QPCR assay was linear over the expected range of $\beta_{1}$ receptor mRNA concentrations, we added increasing amounts of in vitro transcribed $\beta_{1}$ receptor mRNA to poly $(\mathrm{A})^{+}$-enriched RNA that contained a $\beta_{1}$ mRNA abundance of $2.5 \times 10^{7}$ molecules/ $\mu \mathrm{g}$. Using either 0.25 or $0.50 \mathrm{pg}$ of cRNA as the internal stan- 


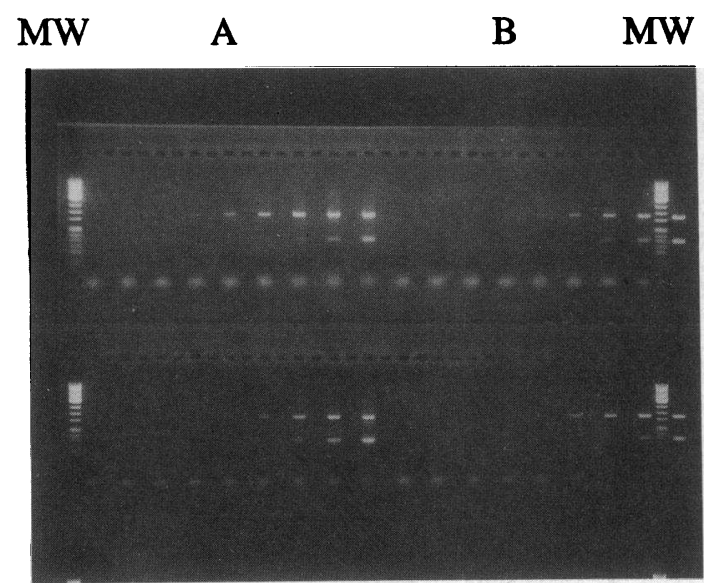

C

D

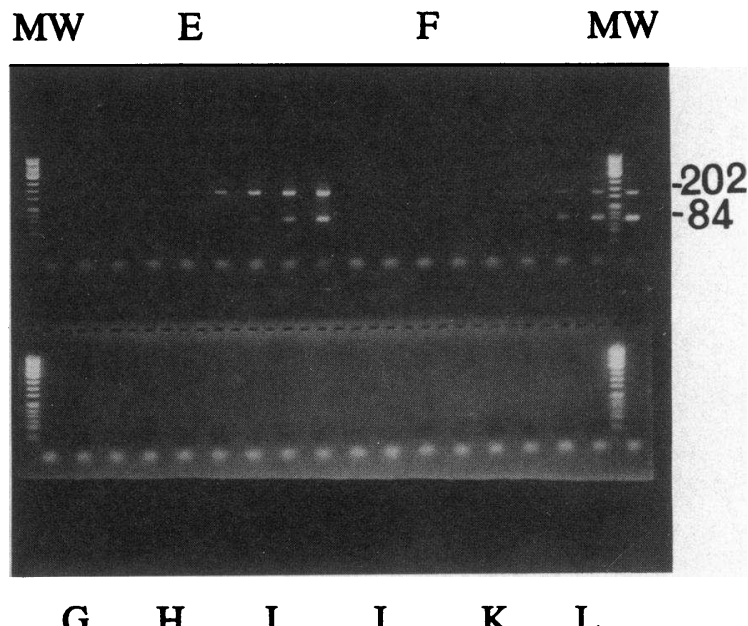

G $\quad$ H $\quad$ I $\quad$ J $\quad$ K $\quad$ L

Figure 2. Agarose gels containing the fractionated contents of six separate PCR reactions using poly $(\mathrm{A})^{+}$-enriched RNA subjected to reverse transcription and PCR. Amplified $\beta_{1}$ receptor mRNA appears as a 202-bp product, and the 84-bp product is the internal standard. $M W$, molecular weight markers. 10- $\mu$ l aliquots were removed from the PCR reaction in cycles 14, 17, 19, 21, 24, 25, 27, 29, and 32, in lanes $1-9$ from left to right. $G-L$ are cycles 14,25 , and 32 for each of six samples in which reverse transcriptase was omitted ("genomic control").

dard, the assay was linear with respect to added mRNA from measured values of $2.5 \times 10^{7}$ to $18 \times 10^{7}$ molecules $/ \mu \mathrm{g}$ $\operatorname{poly}(\mathrm{A})^{+}$RNA.

Table I gives the QPCR quantification of $\beta_{1}$ mRNA in poly $(\mathrm{A})^{+}$-enriched samples from 13 failing and 12 nonfailing human hearts. Compared to nonfailing controls, failing hearts had a $50 \%$ lower abundance of $\beta_{1}$-adrenergic receptor mRNA. This finding was similar to the $56 \%$ lower density of $\beta_{1}$ receptor observed in the failing vs. nonfailing heart and $\beta_{2}$ receptor mRNA abundance.

$\beta_{2}$ receptor $m R N A$ abundance. $\beta_{2}$ receptor mRNA abundance was also measured by QPCR, in total RNA extracted from nonfailing and failing human hearts (Table II). In contrast to $\beta_{1}$ receptor mRNA, collinear amplification of reversetranscribed $\beta_{2}$ message always occurred in $<30$ cycles. Genomic amplification was not observed for the $\beta_{2}$ mRNA assay, presumably because of the lower PCR cycle requirements (data not shown). As can be seen in Table I, there was no difference $(P=\mathrm{NS})$ in $\beta_{2}$ receptor mRNA abundance or $\beta_{2}$ receptor density between nonfailing and failing hearts.

Relation between $\beta_{1}$ receptor $m R N A$ abundance and $\beta_{1}$ or $\beta_{2}$ receptor density. Fig. 5 gives the simple regression relation between QPCR-measured $\beta_{1}$ receptor mRNA abundance and $\beta_{1}$ or $\beta_{2}$ receptor density in the 25 ( 13 failing and 12 nonfailing) left ventricles. There is a significant direct relation between $\beta_{1}$ mRNA and $\beta_{1}$ receptor density (top panel, $r=0.52, P=0.008$ ) but no relation between $\beta_{1}$ mRNA and $\beta_{2}$ receptor density (bottom panel, $r=0.07, P=\mathrm{NS}$ ).

\section{RNase protection}

Nuclease protection assays were also used to measure $\beta_{1}$ mRNA abundance, in total RNA extracted from explanted failing and nonfailing hearts. A representative autoradiogram from an RNase protection assay utilizing probe I in total RNA is shown in Fig. 6. In Table II are given the $\beta_{1}$ mRNA abundance measurements for probes I and II, and for the average of both probes when both were used in the same sample. The abundance of $\beta_{1}$ mRNA was less in failing than in nonfailing hearts, confirming the results of quantitative PCR. Using the average data for both probes, $\beta_{1}$ receptor mRNA was decreased by $50.2 \%$ and $\beta_{1}$ receptor density by $65.2 \%$ in the same hearts (Table II). As shown in Fig. 7, $\beta_{1}$ mRNA measurement by RNase protection was highly correlated $(r=0.90, P<.001)$ with QPCR measurements in the same samples, which in-

Table I. $\beta_{1}$ and $\beta_{2}$ Receptor MRNA Abundances Measured by QPCR and $\beta_{1}$ and $\beta_{2}$ Receptor Densities in Nonfailing and Failing Human Left Ventricular Myocardium

\begin{tabular}{|c|c|c|c|c|}
\hline$\underset{(n)}{\text { Group }}$ & $\beta_{1}$ mRNA abundance & $\beta_{1}$ receptor density & $\beta_{2}$ mRNA abundance & $\beta_{2}$ receptor density \\
\hline & $\begin{array}{c}\text { molecules } \times 10^{7} / \mu g \\
\operatorname{poly}(A)^{+} R N A\end{array}$ & $\mathrm{fmol} / \mathrm{mg}$ & $\begin{array}{c}\text { molecules } \times 10^{7} / \mu g \\
\text { total } R N A\end{array}$ & $\mathrm{fmol} / \mathrm{mg}$ \\
\hline \multicolumn{5}{|c|}{ Nonfailing } \\
\hline (12) & $4.2 \pm 0.7$ & $67.9 \pm 6.9$ & $2.2 \pm 0.6$ & $22.1 \pm 1.9$ \\
\hline \multicolumn{5}{|l|}{ Failing } \\
\hline (13) & $2.1 \pm 0.3^{*}$ & $29.6 \pm 3.5^{*}$ & $1.6 \pm 0.3$ & $17.7 \pm 1.3$ \\
\hline
\end{tabular}

Values are given \pm SEM. ${ }^{*} P<0.01$ vs. nonfailing controls. 


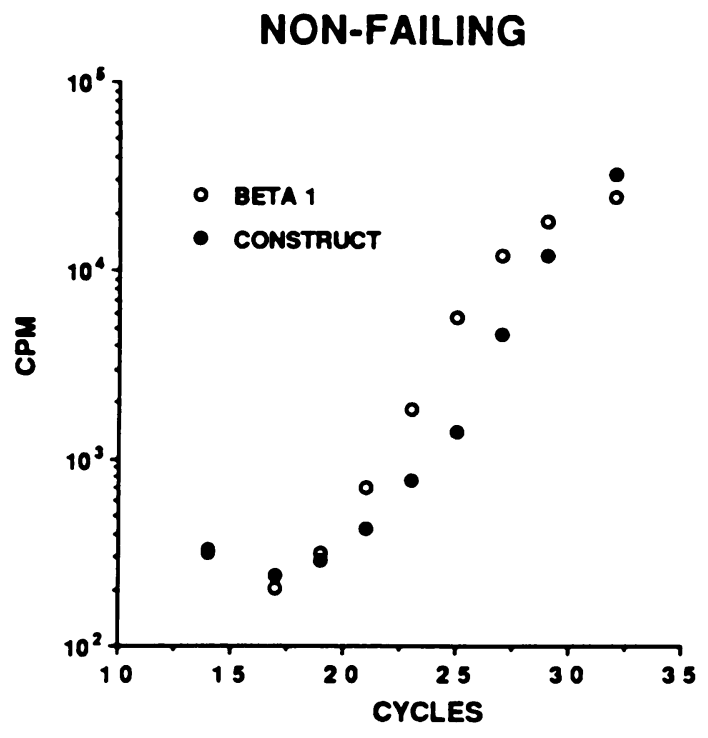

FAILING

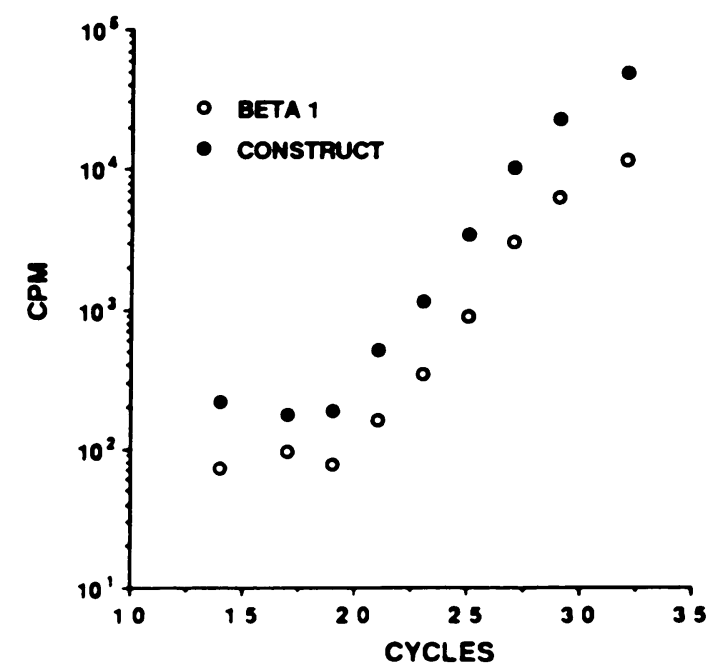

NON-FAILING

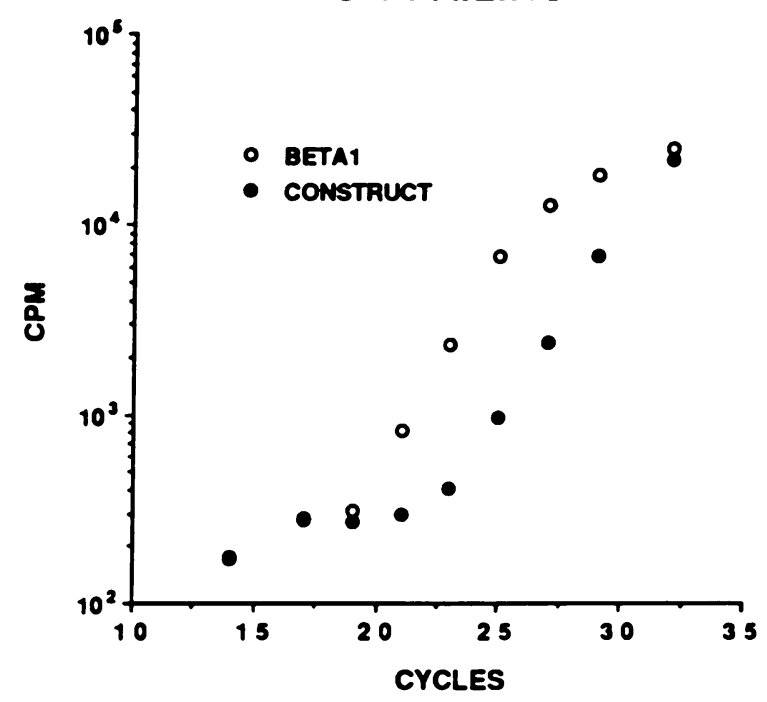

FAILING

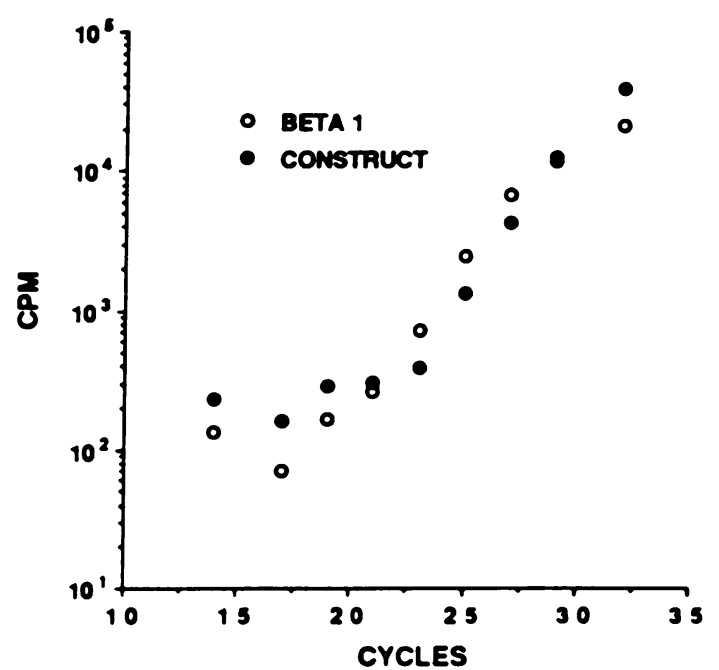

Figure 3. PCR amplification of reverse transcription products (cDNA) of $\beta_{1}$ receptor mRNA from poly $(\mathrm{A})^{+}$-enriched RNA $(\cdot$, BETA 1$)$ and internal standard cRNA from the $\beta_{1}$ construct ( $\bullet$, CONSTRUCT).

cluded RNA extracted from four nonfailing and six failing ventricles.

To verify the specificity of the antisense probes full-length sense human $\beta_{2}$-adrenergic receptor mRNA was transcribed and hybridized to both antisense $\beta_{1}$ probes. The two $\beta_{1}$ antisense probes used were highly specific for $\beta_{1}$-adrenergic receptor mRNA, as neither the SmaI (probe I) nor the EagI $\beta_{1}$ probe (probe II) protected a fragment of $\beta_{2}$ mRNA of the correct size (data not shown).

As the $\beta_{1}$-adrenergic receptor gene is apparently intronless (Fig. 1), protection of genomic DNA present as a contaminant in the RNA preparations could be a potential problem as it was with QPCR. Accordingly, RNA extracted from a nonfailing heart was treated with DNAse I before hybridization with the SmaI riboprobe. By densitometry the abundance of $\beta_{1}$ mRNA in DNAse I treated total RNA was no different from the abundance of $\beta_{1}$ mRNA in untreated total RNA from the same sample (data not shown).

\section{Discussion}

Using QPCR we have previously reported that the failing human heart exhibits marked abnormalities of gene expression, including de novo expression of atrial natriuretic peptide mRNA and decreased levels of phospholamban mRNA (13). Furthermore, these changes in gene expression are potentially reversible with restoration of normal cardiac function (23).

Within the context of the altered $\beta$ receptor-G-proteinadenylyl cyclase signal transduction pathways in the failing heart, the molecular mechanisms responsible for the various described abnormalities ( $1-5$ ) remain elusive. The mRNA levels for the $\beta_{2}$ adrenergic receptor (19) and the G proteins, $G_{\alpha s}$ (19) and $G_{\alpha i 3}(19)$, are not different in total RNA extracted from failing and nonfailing human ventricular myocardium. This is not totally unexpected, since the respective gene products are not quantitatively altered in the failing human heart (5). Based on previous work in the failing human heart $(2,3)$ 


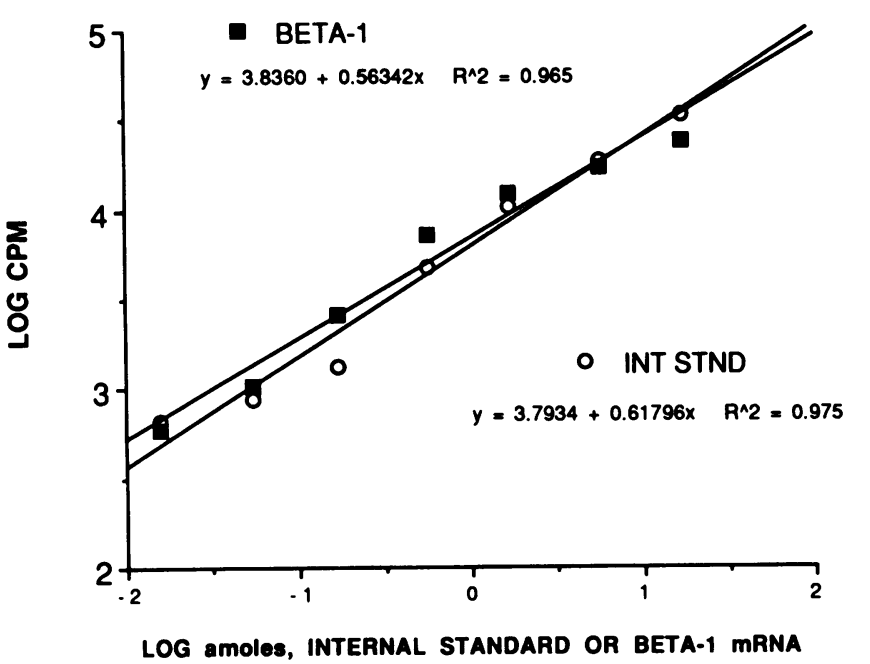

Figure 4. Simultaneous measurement of identical molar amounts of $\beta_{1}$ receptor mRNA ( $\left.-B E T A-1\right)$ and $\beta_{1}$ cRNA internal standard (standard $\cdot$, INT STND) by quantitative PCR.

and in cell culture model systems $(10,11)$, one element of the receptor-G-protein-adenylyl cyclase complex that is a strong candidate for abnormal gene expression is the $\beta_{1}$-adrenergic receptor.

By Northern analysis or QPCR $\beta_{1}$-adrenergic receptor mRNA abundance measurements in total RNA extracted from human heart have thus far been unreliable, due to low abundance of the $\mathrm{G}+\mathrm{C}$ rich $\beta_{1}$ receptor message (17) and genomic contamination of PCR products. Based on the structures of closely related genes $(20,24)$ and our PCR data the $\beta_{1}$-adrenergic receptor gene likely contains no introns, and therefore PCR primers could not be chosen to differentiate the cDNA amplification signal from that of genomic DNA. The need for high cycle numbers $(>35)$ in detecting this low-abundance message exacerbated the genomic DNA contamination problem. Consequently, it was necessary to use poly $(A)^{+}$enriched RNA as the starting material. In using these conditions, fewer than 32 cycles of PCR were required to produce satisfactory levels of amplification. Furthermore, under these conditions, amplifications of non-reverse-transcribed [RT $(-)$ ] RNA produced no detectable signal, indicating the elimination of genomic DNA contamination.

In using quantitative QPCR it is mandatory that collinear amplification be obtained with the internal standard. This, in turn, requires that approximately equal amounts of internal standard and mRNA are present in the initial reaction mixture. Additionally, it is important that this collinear amplification occur at relatively low cycle numbers (i.e., $<35$ ), to avoid artifacts caused by PCR. These criteria were satisfied by the above described assay conditions.

In failing ventricles, steady-state $\beta_{1}$ receptor mRNA levels measured by QPCR were $50 \%$ lower than in nonfailing control hearts. In these same failing hearts $\beta_{1}$ receptor density was $56 \%$ lower than in nonfailing controls. Moreover, when all 25 ventricles in which $\beta_{1}$ receptor mRNA abundance was measured were considered, there was a direct relation between $\beta_{1}$ mRNA abundance and $\beta_{1}$ receptor density, but no relation between $\beta_{1}$ mRNA and $\beta_{2}$ receptor density. The degree of down-regulation of mRNA and the degree of down-regulation of $\beta_{1}$-adrenergic
Table II. $\beta_{1}$ Receptor mRNA Abundance Measured by RNase Protection and $\beta_{1}$-Adrenergic Receptor Density in Nonfailing and Failing Human Ventricular Myocardium

\begin{tabular}{|c|c|c|c|c|}
\hline Group & $\begin{array}{c}\text { Probe I } \\
\text { (Smal digest) }\end{array}$ & $\begin{array}{c}\text { Probe II } \\
\text { (Eagl digest) }\end{array}$ & $\begin{array}{c}\text { Both } \\
\text { riboprobes }\end{array}$ & $\begin{array}{l}\beta_{1} \text { receptor } \\
\text { density }\end{array}$ \\
\hline & & $\%$ of control & & $\mathrm{fmol} / \mathrm{mg}$ \\
\hline Nonfailing & $\begin{array}{c}100.6 \pm 13.3 \\
(n=7)\end{array}$ & $\begin{array}{c}99.5 \pm 19.1 \\
(n=4)\end{array}$ & $\begin{array}{c}99.4 \pm 9.5 \\
(n=7)\end{array}$ & $\begin{array}{c}83.0 \pm 10.3 \\
(n=7)\end{array}$ \\
\hline Failing & $\begin{array}{c}52.3 \pm 9.0^{*} \\
(n=6)\end{array}$ & $\begin{array}{c}48.8 \pm 9.3^{*} \\
(n=6)\end{array}$ & $\begin{array}{c}49.7 \pm 6.6^{*} \\
(n=6)\end{array}$ & $\begin{array}{c}29.9 \pm 4.2^{*} \\
(n=6)\end{array}$ \\
\hline
\end{tabular}

Values are given \pm SEM. ${ }^{*} P<.05$ vs. nonfailing.

receptors were therefore quite similar considering the vast array of factors which could potentially influence the regulation of both mRNA and proteins. These factors include altered transcriptional and translation frequency, mRNA stability, and receptor protein turnover. Also, the fact that the nonfailing controls were obtained from organ donors who are invariably subjected to very high levels of endogenous sympathetic drive due to brain injury (25) cannot be ignored. Since the kinetics of mRNA turnover are likely to be faster than receptor turnover (i.e., mRNA half-life vs. protein half-life), it may be that mRNA abundance was already beginning to decrease in the nonfailing controls.

Decreased $\beta_{1}$ receptor mRNA in failing left ventricles was confirmed by $R$ Nase protection assay, which showed a relative decrease in message levels by $50 \%$ in six failing hearts. The presence of $\beta_{1}$ receptor genomic material contaminating the total RNA in these assays did not pose a problem, presumably due to the preference of the riboprobes for RNA-RNA vs. RNA-DNA hybridization (26). Of the two riboprobes, the 3' UTR probe (SmaI digest, probe I) gave the best hybridization signal. Both probes were specific for $\beta_{1}$ receptor mRNA, as in vitro transcribed $\beta_{2}$ mRNA did not cross-protect against RNase degradation. The fact that in two RNA fractions two totally independent methods, QPCR and RNase protection, yielded decreased $\beta_{1}$ receptor mRNA abundance measurements in failing human heart provides strong evidence that transcript steady-state level is one important determinant of $\beta_{1}$ receptor regulation in human ventricular myocardium.

Despite the $50 \%$ decrease in $\beta_{1}$ mRNA in poly $(\mathrm{A})^{+}$. enriched or total RNA extracted from failing human hearts $\beta_{2}$ mRNA abundance in total RNA was similar in failing and in nonfailing ventricles. This is in agreement with our previously reported data in total RNA (19). Apparently because $\beta_{2}$ receptor mRNA abundance is greater than $\beta_{1}$ in the human heart, QPCR can be performed in total RNA with relatively low $(<30)$ cycle numbers and genomic contamination can be avoided (19).

There are two previous reports of QPCR measurements of $\beta_{1}$ receptor mRNA in failing human ventricular myocardium, one reporting an increase compared to nonfailing controls (27) and one reporting a decrease (28). In the previous report showing a decrease (28), 38 cycles of PCR were used on total RNA and no RT( - ) control condition was reported. The report of an increase in $\beta_{1}$ mRNA in failing ventricles also used total RNA (27). Again, the combination of low abundance and an 

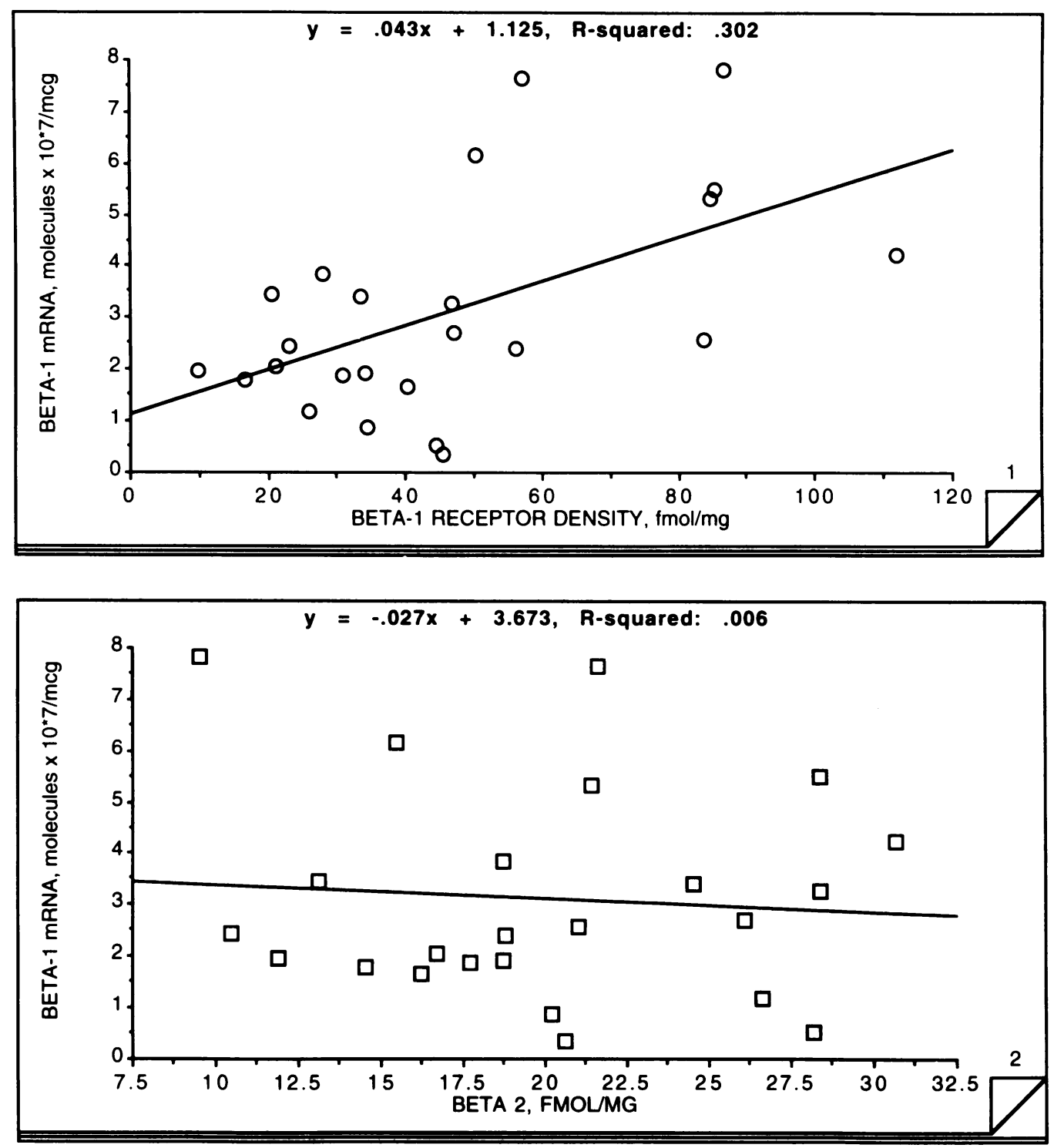

Figure 5. Simple regression plots of $\beta_{1}$ receptor mRNA $\left(y\right.$-axis) vs. $\beta_{1}$ receptor density (top panel) and $\beta_{2}$ receptor density (bottom panel) in the 25 left ventricles in which $\beta_{1}$ mRNA abundance was measured by QPCR.

\section{$\begin{array}{lllllllllll}1 & 2 & 3 & 4 & 5 & 6 & 7 & 8 & 9 & 10 & 11\end{array}$}

Figure 6. A representative autoradiogram of an RNase protection assay. Total RNA extracted from explanted human hearts was hybridized with an $\left[\alpha^{32} \mathrm{P}\right]$ UTP-labeled antisense $\beta_{1}$ riboprobe (SmaI digest of $\beta_{1}$ cDNA; 450-bp probe). Fragments protected from RNase digestion were resolved by denaturing gel electrophoresis and visualized by autoradiogram. Lanes 1 and 2 : Sma I antisense $\beta_{1}$ riboprobe without (lane 1 ) and with (lane 2) RNase treatment; lane 2 contains eight times the amount of riboprobe as lanes 1 or $3-8$. The smaller, faster migrating bands
present in all lanes are probably self-protected probe fragments. As the probe is very $G+C$ rich (17), higher order structures in the single stranded antisense probe are likely to be present, even under denaturing conditions. These structures will protect portions of the probe from RNase digestion. Lanes 3, 4, and 5: synthetic $\beta_{1} \mathrm{mRNA}(200,100$, and $50 \mathrm{pg})$ hybridized with the labeled $\beta_{1}$ riboprobe. The prominent lower bands in the standard lanes are most likely due to premature termination of transcription of the synthetic sense $\beta_{1}$ mRNA. Lanes 6 , 7, and 8 : Total RNA from three different explanted nonfailing human hearts hybridized with the antisense $\beta_{1}$ riboprobe. Lanes 9,10 , and 11: Total RNA from three different explanted failing human hearts hybridized with the antisense $\beta_{1}$ riboprobe. $\beta_{1}$ mRNA abundance is significantly lower in failing human hearts compared to the abundance in nonfailing human hearts as determined by RNase protection assay. 


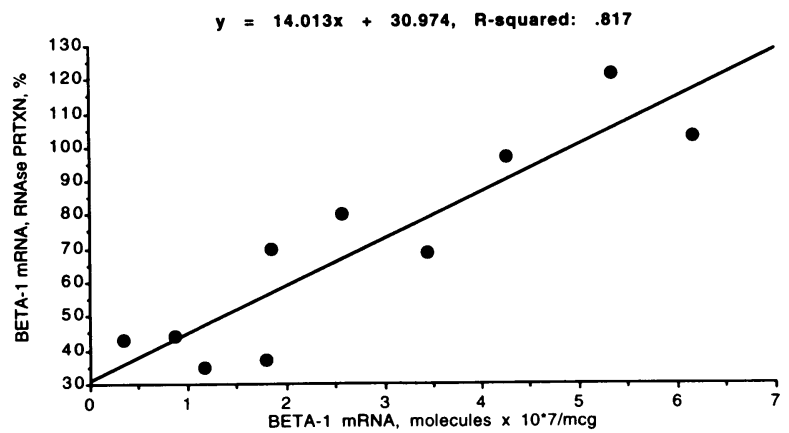

Figure 7. Correlation of $\beta_{1}$ mRNA abundance measured by QPCR in poly $(\mathrm{A})^{+}$-enriched RNA vs. measurement by $\mathrm{RNase}$ protection in total RNA; four nonfailing and six failing human left ventricles.

intronless gene makes measurements of $\beta_{1}$ receptor mRNA levels by QPCR challenging, and unreliable in total RNA using high $(>30)$ cycle numbers. Depending on the DNA/RNA ratio in myocardium comprising the starting material, $\beta_{1}$ "mRNA" abundance in total RNA could be found to be increased or decreased.

There are two previous reports of RNase protection performed as solution hybridization with the hybrids isolated by filtration $(29,30)$. Although identical riboprobes were used in these two investigations $(29,30)$, one study in idiopathic dilated cardiomyopathy found an increase in $\beta_{1}$ receptor "mRNA" (30) and the other in valvular heart disease (30) found a decrease. Based on the number of self-protecting fragments detected on acrylamide gels in our own RNase protection assays, it is obvious that the appropriately sized RNA:RNA hybrid needs to be separated and isolated by gel electrophoresis. Unless it has been documented that a single protected or a very dominant protected product accounts for the overwhelming majority of the measured radioactivity in the solution assay, filtration isolation of hybridized material can lead to spurious results. Circumstances such as these may have contributed to the divergent results in these two previous studies $(29,30)$.

Although the starting material (left ventricular myocardium) used for mRNA and receptor measurements was multicellular, the majority of cell volume, protein, and RNA in ventricular myocardium is derived from cardiac myocytes. In mammalian ventricles $\beta_{1}$ adrenergic receptors are selectively expressed in myocardial cells (31), and therefore it is likely that the vast majority of $\beta_{1}$ receptor protein and mRNA measured in this investigation was derived from cardiac myocytes. We have previously shown that this is in fact the case for $\beta_{1}$-adrenergic receptors measured in crude membrane fractions extracted from human ventricles (2).

In summary, $\beta_{1}$ receptor mRNA abundance is lower in the failing human heart than in nonfailing, control hearts. This decrease can fully account for the observed down-regulation of $\beta_{1}$-adrenergic receptor expression in failing hearts. Further studies will be required to determine the molecular basis for this alteration in gene expression.

\section{Acknowledgments}

We wish to thank Dr. Carl T. Wittwer of the University of Utah Medical School for helpful suggestions on optimal conditions for PCR, Dr.
M. Benjamin Perryman for critical review of the manuscript, and Frank Stewart for manuscript preparation.

This work was supported by National Institutes of Health (NIH) grants HL-13408-15 and HL-48013-01 A2, awarded to Dr. Michael R. Bristow. Dr. Arthur M. Feldman was supported by NIH Program Grant HL-39719 and The W. W. Smith Charitable Trust.

\section{References}

1. Bristow, M. R., R. Ginsburg, W. Minobe, R. S. Cubicciotti, W. S. Sageman, K. Lurie, M. E. Billingham, D. C. Harrison, and E. B. Stinson. 1982. Decreased catecholamine sensitivity and $\beta$-adrenergic-receptor density in failing human hearts. N. Engl. J. Med. 307:205-211.

2. Bristow, M. R., R. Ginsburg, M. Fowler, W. Minobe, R. Rasmussen, P. Zera, R. Menlove, P. Shah, and E. Stinson. 1986. $\beta_{1}$ and $\beta_{2}$ adrenergic receptor subpopulations in normal and failing human ventricular myocardium: coupling of both receptor subtypes to muscle contraction and selective $\beta_{1}$ receptor downregulation in heart failure. Circ. Res. 59:297-309.

3. Brodde, O. R., S. Schuler, R. Kretsch, M. Brinkmann, H. G. Borst, R. Hetzer, J. C. Reidemeister, W. Warnecke, and H. R. Zerkowski. 1986. Regional distribution of $\beta$-adrenoceptors in the human heart: coexistence of function $\beta_{1^{-}}$ and $\beta_{2}$-adrenoceptors in both atria and ventricles in severe congestive cardiomyopathy. J. Cardiovasc. Pharmacol. 8:1235-1242.

4. Bristow, M. R., W. Minobe, R. Rasmussen, P. Larrabee, L. Skerl, J. W. Klein, F. L. Anderson, L. Murray, L. Mestroni, S. V. Karwande, et al. 1992. $\beta$-Adrenergic neuroeffector abnormalities in the failing human heart are produced by local, rather than systemic mechanisms. J. Clin. Invest. 89:803-815.

5. Bristow, M. R., R. E. Hershberger, J. D. Port, E. M. Gilbert, A. Sandoval, R. Rasmussen, A. E. Cates, and A. M. Feldman. 1990. $\beta$-Adrenergic pathways in nonfailing and failing human ventricular myocardium. Circulation. 82(Suppl. I): $12-25$.

6. Port, J. D., and M. R. Bristow. 1988. Lack of spare $\beta$-adrenergic receptors in the human heart. FASEB J. 2:A602.

7. Brown, L., N. M. Deighton, S. Bals, W. Sohlmann, H. R. Zerkowski, M. C. Michel, and O. E. Brodde. 1992. Spare receptors for $\beta$-adrenoceptor-mediated positive inotropic effects of catecholamines in the human heart. $J$. Cardiovasc. Pharmacol. 19:222-232.

8. Hadcock, J. R., and C. C. Malbon. 1988. Down-regulation of beta-adrenergic receptors: agonist-induced reduction in receptor mRNA levels. Proc. Natl. Acad. Sci. USA. 85:5021-5025.

9. Hadcock, J. R., H. Y. Wang, and C. C. Malbon. 1989. Agonist-induced destabilization of $\beta$-adrenergic receptor mRNA: attenuation of glucocorticoid-induced up-regulation of $\beta$-adrenergic receptors. J. Biol. Chem. 264:19928-19933.

10. Bristow, M. R., C. Durham, J. Klein, R. Rasmussen, J. D. Port, R. R. Gesteland, W. H. Barry, and A. M. Feldman. 1991. Down-regulation of $\beta$-adrenergic receptors and receptor mRNA in heart cells chronically exposed to norepinephrine. Clin. Res. 39:256A. (Abstr.)

11. Lazar-Wesley, E., J. R. Hadcock, C. C. Malbon, G. Kunos, and E. J. Ishac. 1991. Tissue-specific regulation of $\alpha_{1 \mathrm{~B}}, \beta_{1}$, and $\beta_{2}$-adrenergic receptor mRNAs by thyroid state in the rat. Endocrinologv. 129:1116-1118.

12. Wang, A. M., M. V. Doyle, and D. F. Mark. 1989. Quantitation of mRNA by the polymerase chain reaction. Proc. Natl. Acad. Sci. USA. 86:9717-9721.

13. Feldman, A. M., P. E. Ray, C. M. Silan, J. A. Mercer, W. Minobe, and M. R. Bristow. 1991. Selective gene expression in failing human heart. Circulation. 83:1866-1872.

14. Bouaboula, M., P. Legoux, B. Pessegue, B. Delpech, X. Dumont, M. Piechaczyk, P. Casellas, and D. Shire. Standardization of mRNA titration using a polymerase chain reaction method involving co-amplification with a multispecific internal control. 1992. J. Biol. Chem. 267:21830-21838.

15. Lee, J. J., and N. A. Costlow. 1987. A molecular titration assay to measure transcript prevalance levels. Methods Enzymol. 152:633-648.

16. Chomczynski, P., and N. Sacchi. 1987. Single-step method of RNA isolation by acid guanidinion thiocyanate-phenol-chloroform extraction. Anal. Biochem. 1622:156-159.

17. Frielle, T., S. Collins, K. W. Daniel, M. G. Caron, R. J. Lef kowitz, and B. K. Kobilka. 1987. Cloning of the cDNA for the human beta 1-adrenergic receptor. Proc. Natl. Acad. Sci. USA. 84:7920-7924.

18. Kawasaki, E. S. 1990. Amplification of RNA. In PCR Protocols-A Guide to Methods and Applications. M. A. Innis and D. H. Gelfand, editors. Academic Press, Inc., San Diego, CA. 3-12.

19. Feldman, A. M., P. E. Ray, and M. R. Bristow. 1991. Expression of $\alpha$-subunits of $\mathrm{G}$ proteins in failing human heart: a reappraisal utilizing quantitative polymerase chain reaction. J. Mol. Cell. Cardiol. 23:1355-1358.

20. Dixon, R. A. F., B. K. Kobilka, D. J. Strader, J. L. Benovic, H. G. Dohlman, T. Frielle, M. A. Bolanowski, C. D. Bennett, E. Rands, R. A. Diehl, et al. 1986. Cloning of the gene and cDNA for mammalian $\beta$-adrenergic receptor and homology with rhodopsin. Nature (Lond.). 321:75-79. 
21. Peterson, G. L. 1977. A simplification of the protein assay method of Lowry et al. which is more generally applicable. Anal. Biochem. 83:346-356.

22. Gyllensten, U. B., and H. A. Erlich. 1988. Generation of single-stranded DNA by the polymerase chain reaction and its application to direct sequencing of the HLA-DQA locus. Proc. Natl. Acad. Sci. USA. 85:7652-7656.

23. Ladenson, P. W., S. I. Sherman, K. L. Baughman, P. E. Ray, and A. M. Feldman. 1992. Reversible alterations in myocardial gene expression in a young man with dilated cardiomyopathy and hypothyroidism. Proc. Natl. Acad. Sci. USA. 89:5251-5255.

24. Shimomura, H., and A. Terada. 1990. Primary structure of the rat beta-1 adrenergic receptor gene. Nucleic Acids Res. 18:4591.

25. Hamill, R. W., P. D. Woolf, J. V. McDonald, L. A. Lee, and M. Kelly. 1987. Catecholamines predict outcome in traumatic brain injury. Ann. Neurol. 21:438-443.

26. Sambrook, J., E. F. Fritsch, and T. Maniatis. 1989. Molecular Cloning, a Laboratory Manual. 2nd edition. Cold Spring Harbor Press, Cold Spring Harbor, NY.
27. Ihl-Vahl, R., R. Marquetant, and R. H. Strasser. 1992. Subtype-selective regulation of mRNA for $\beta_{1}$-adrenergic receptor in chronic heart failure. Circulation. 86(Suppl. I):I-767. (Abstr.)

28. Ungerer, M., M. Bohm, J. S. Elce, E. Erdmann, and M. J. Lohse. 1993. Altered expression of $\beta$-adrenergic receptor kinase and $\beta_{1}$-adrenergic receptors in the failing human heart. Circulation. 87:454-463.

29. Sylven, C., M. Bronnegard, E. Jansson, P. Sotonyi, F. Liang-Xiong, F. Waagstein, and $A$. Hjalmarsson. 1992. Increased $\beta_{1}$ receptor expression at mRNA level in dilated cardiomyopathy. J. Am. Coll. Cardiol. 19:273A. (Abstr.)

30. Sylven, C., P. Arner, L. Hellstrom, E. Jansson, P. Sotonyi, A. Somogyi, and M. Bronnegard. 1991. Left ventricular $\beta_{1}$ and $\beta_{2}$ adrenoceptor mRNA expression in normal and volume overloaded human heart. Cardiovasc. Res. 25:737-741.

31. Murphree, S. S., and J. E. Saffitz. 1988. Delineation of the distribution of beta-adrenergic receptor subtypes in canine myocardium. Circ. Res. 63:117-125. 